\title{
Ready for more-than-human? Measuring urban residents' willingness to coexist with animals
}

\author{
CHRISTOPH D. D. RUPPRECHT
}

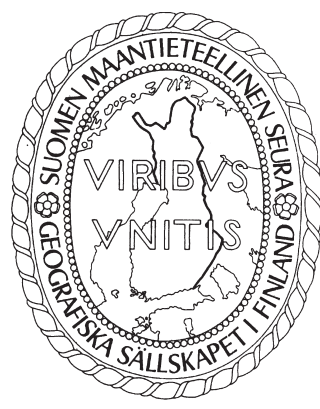

Rupprecht, Christoph D. D. (2017). Ready for more-than-human? Measuring urban residents' willingness to coexist with animals. Fennia 195: 2, pp. 142160. ISSN 1798-5617.

$\mathbf{y}$ In the context of rapid urbanisation, geographers are calling for embracing non-humans as urban co-inhabitants. But if animals and plants are seen as 'out of place', sharing urban space can lead to wildlife conflicts. We therefore need to better understand residents' willingness to coexist if we are to work towards more-than-human cities. This study quantitatively compared residents' preferences toward sharing their neighbourhood, as well as perceptions of belonging across urban green space in two geographically and culturally distinct cities: Brisbane, Australia, and Sapporo, Japan. Results suggest that geographical and cultural context alongside educational attainment and age influenced respondents' willingness to coexist, but not sex and income. Mapping respondents' preferences for animals in their neighbourhood revealed four groups of animals along two axes - global-local and wantedunwanted. These arose from the way animals contested the human notions of control over urban space. As spaces where animals belong in cities, most respondents chose informal green space (e.g. vacant lots, brownfields) after forests and bushland. Drawing upon recent theoretical and empirical research on liminal urban spaces, I argue that such informal green space can offer 'provisional arrangements' which allow for conciliatory engagements with non-humans. I thus propose informal green spaces as territories of encounter - a possible path towards morethan-human cities. Finally, I discuss some implications for planning and management of interspecies interactions.

Keywords: urban geography, belonging, wildlife conflict, informal green space, human-nonhuman relations

Christoph D. D. Rupprecht, FEAST Project, Research Institute for Humanity and Nature, 457-4 Motoyama, Kamigamo, Kita-ku, Kyoto, 603-8047 Japan, E-mail: crupprecht@chikyu.ac.jp

\section{Introduction: In search of pathways towards more than human cities}

"Recurrent invasions racked the city of Theodora in the centuries of its history; no sooner was one enemy routed than another gained strength and threatened the survival of the inhabitants. When the sky was cleared of condors, they had to face the propagation of serpents; the spiders' extermination allowed the flies to multiply into a black swarm; the victory over the termites left the city at the mercy of the woodworms. One by one the species incompatible to the city had to 
succumb and were extinguished. By dint of ripping away scales and carapaces, tearing off elytra and feathers, the people gave Theodora the exclusive image of human city that still distinguishes it. [...] Man had finally re-established the order of the world which he had himself upset: no other living species existed to cast any doubts." (Calvino 2013, 49)

Do we as urban residents want to share our cities? Whom do we welcome, whom do we (try to) expel? How do we decide who is out of place, and where they are not? In the face of ongoing global urbanisation, scholars have looked beyond human inhabitants. They have opened their eyes to urban landscapes teeming with micro-organisms, plants and animals, prompting a (second) renaissance of urban ecological studies (Gilbert 1989; Sukopp 2002). Simultaneously, increased interest in animal geography and urban human-nature relations has led to growing calls for cities where non-humans belong (Wolch et al., 1995; Wolch 1996, 2002; Hinchliffe et al. 2005; Hinchliffe \& Whatmore 2006; Seymour \& Wolch 2009; Metzger 2014).

In this article, I aim to discover what chances and challenges such an embracing approach towards nonhumans might entail. Drawing upon theoretical and empirical work in urban human-nature geographies, I test a quantitative approach to learn about people's willingness to coexist with animals and plants. Results of an exploratory mail-back survey in Brisbane, Australia, and Sapporo, Japan, suggest that geographic and cultural, and to some degree demographic differences, configure willingness to coexist with wildlife. Where residents think non-humans belong in the city, and whether animals contest physical and ideological urban boundaries further influence how space is negotiated. Based on these results, I argue that informal urban green spaces (which I discuss in more detail below), where our expectations of human control are weaker, may offer 'provisional arrangements' (Nohl 1990) as potential territories of encounter - and thus could be a path towards more-than-human cities.

Our 'entanglement' with life around us is nowhere more apparent than in the city (Ingold 2008). Urban ecosystems provide a plethora of services by filtering our air, reducing noise, draining rainwater that might otherwise sweep away our homes, and treat the sewage we produce (Bolund \& Hunhammar 1999). Scholars have described how our urban selves have 'nature needs' (Matsuoka \& Kaplan 2008) and have provided growing evidence for a strong link between our health and urban greenspace (Brown \& Cummins 2013; Keniger et al. 2013; van den Berg et al. 2015). These ecosystem services depend at least partly on a diversity of species we are entangled with (Mace et al. 2012). For example, without opportunities for urban residents to interact with nature, this 'extinction of experience' (Miller 2005; Soga et al. 2015) could affect biodiversity beyond cities as conservation efforts depend on public support (Dunn et al. 2006). As city dwellers, we also draw upon the (agro) diversity in our community gardens to supply us (and the microorganisms that reside within us (Bordenstein \& Theis 2015)) with the vitamins and minerals we need (Guitart et al. 2014). Yet sometimes we reject these ties and try to sever them.

Urban wildlife conflicts are ubiquitous. We struggle with plants over space and belonging (Gröning \& Wolschke-Bulmahn 2003; Head \& Atchison 2008; Foster \& Sandberg 2010; Rupprecht et al. 2015a) and with animals such as rats, monkeys, bears, deer, birds, bees over space and plants (Knight 1999; Jerolmack 2008; Honda 2009; Enari \& Suzuki 2010; Yeo \& Neo 2010; Lemelin 2013; Belaire et al. 2015). We are bitten by mosquitos, ants, spiders or coyotes (Howell 1982), reduced to helpless sneezing or worse by various plant pollen, subjected to aerial bombardments by defecating birds, and feel offended in various ways by all matter of animals and plants in what have come to be known as 'ecosystem disservices' (Lyytimäki et al. 2008; von Döhren \& Haase 2015). We retaliate with herbicides, pesticides and 'management' of urban wildlife (Wolch et al. 1995; Jessup 2004; Adams 2012; Rupprecht et al. 2015a), seeking to establish dominance.

What paths then lead to more-than-human cities? Wolch, West and Gaines $(1995,755)$ lay out the foundations for a transspecies urban theory to foster creation of "an environmental ethic that recognises the fundamental linkages between human justice and justice for animals". Rather than an uneasy stand-off, they aim for "a city whose residents reincorporate wild animals into everyday human affairs by respecting their dignity and value, by accepting the duty to know their ways of living" (Wolch et al. 1995, 746). However, a case study about an intentional community committed to fostering human-animal relations showed that not all animals were equally welcome (Seymour \& 
Wolch 2009). Hinchliffe and Whatmore $(2006,136)$ suggest that "attention be paid to the diversity of ecological attachments and heterogeneous associations through which the politics of urban nature is fabricated, rather than reading the political ecology of the city off a priori or abstract social divisions". This complements Wolch $(2002,735)$, who argues that a major goal in an agenda to reanimate the city would be "to trace how and why attitudes and practices toward animals and patterns of urban human-animal interactions change over time and space". Evidence suggests time and place are not the only things that affect human-animal interactions. The words human-animal or human-plant relationships can hide the multitudes of different entanglements lurking beneath the surface. In his early work among the recent wave of animal geography, Philo (1995) encounters the difficulty of fitting different animals into a continuum of inclusion and exclusion, from pets to lions and urban foxes. Griffith, Wolch and Lassiter (2002) show in their study of culturally based animal practices of Filipinas in the USA that for humans, too, the way we are entangled can vary widely. How to examine these vast lines of entanglement and complex networks?

Researchers in a number of different fields have engaged with the questions raised by humannonhuman urban coexistence, including but not limited to literature in animal studies and morethan-human geography (Hinchliffe 2003; Johnston 2008; van Dooren \& Rose 2012; Lorimer 2012; Urbanik 2012; Buller 2014, 2015), urban political ecology and planning (Philo 1995; Hard 2001; Power 2009; Byrne 2011; Barua 2014; Hillier \& Byrne 2016; Houston et al. 2017), and urban ecology and conservation (McKinney 2008; Barua et al. 2013; Rupprecht et al. 2015a). The specific context of Australia has been the focus of several studies (Anderson 1997; Instone 2004; Power 2005; Davison 2006; Franklin 2006; Instone \& Sweeney 2014; McKiernan \& Instone 2016). The new living bibliography ('Animal Studies Living Bibliography', n.d.) offers a wealth of literature for readers eager to explore this topic in depth. In addition to recent theoretical work on multispecies cities and urban planning (Houston et al. 2017), one important remaining task then is to take a step back from studies focused on individual human-nonhuman relationships, and attempt to quantitatively map an overview of the multitude of relations hiding behind the words 'human' and 'non-human' - a task I take up in this paper.

Quantitative approaches looking at human-nonhuman encounters remain comparatively rare. Nevertheless, they may provide an idea about which non-pet animals feature most prominently in the contestations of space the urban political ecology literature describes, and which factors (e.g. cultural or geographic context, gender, class, race, age) merit further exploration. Drawing upon earlier work on attitudes towards animals (Kellert \& Westervelt 1984; Kellert 1993) but also geographical literature, Bjerke and Østdahl (2004) surveyed Norwegian residents' attitudes towards common urban animals. They found clear preferences for some species, and discovered educational level and gender effects. A study by Sawaki and Kamihogi (1995) in Japan included a spatial element by asking respondents to indicate where they would be comfortable with animals living (e.g. everywhere, their garden or veranda, a park within walking distance, a far-away park or forest, or nowhere). Using this data, they identified different groups based on preferences for species and spaces of coexistence - 'animal lovers', respondents who want to share garden and veranda with preferred animals, those with very strong differences in preferences between animals, and respondents who prefer animals to keep a large distance from them. These studies and an emerging body of similar work show how quantitative approaches may help identify ways towards negotiating more-than-human cities, complementing qualitative research to underpin future theoretical advances in urban human-nature relationships (Bjerke et al. 1998a, 1998b, 2003; Almeida et al. 2014; Borgi \& Cirulli 2015).

Additional gaps exist in our knowledge of human nature relationships apart from the limited number of quantitative studies. Firstly, existing studies were mostly undertaken in Europe, with one study from the USA (Kellert \& Westervelt 1984), one from Japan (Sawaki \& Kamihogi 1995) and one cross-national comparison (Kellert 1993). How such relationships are influenced by geographic or cultural influence thus remains unclear. Secondly, plant-human relationships have not been studied using a quantitative approach, possibly due to our tendency for 'plant blindness' (Wandersee \& Schussler 1999). Sawaki and Kamihogi (1995) further suggest that the spatial aspect, or the question where residents think nature belongs in cities, strongly influences human-nature 
relationships - yet we know little about it. Some urban spaces may be subjected to less human control (e.g. fences, traps, herbicide, or simply less rigid cultural notions of belonging) (Franck \& Stevens 2007). For example, researchers found that informal urban green spaces (IGS) (e.g. vacant lots, street and railway verges, brownfields) were closely associated with wild animals and plants, and perceived as 'neutral ground' not firmly under human control, while also pointing out issues such as ownership and liability as factors limiting the potential of IGS (Rupprecht et al. 2015b, 2016). Could these be 'spaces for nonhumans', spaces where we can engage with them (Hinchliffe et al. 2005)? Knowing whether residents perceive IGS as more of a place of belonging for nature than other urban spaces could inform urban wildlife planning policy. In this paper, I attempt to address some of the gaps outlined above and outline others as directions for future research in the conclusion.

The main research questions addressed in this paper thus are: 1) What knowledge of and attitude toward urban nature underlies residents' encounters with animals?; 2) Who are the main nonhuman actors featuring (positively and negatively) in residents' imagination of their neighbourhood?; 3) How do residents normatively rank urban spaces in terms of where animals and plants should be able to live?; and 4) What factors are influencing residents' in their perception and preferences?

\section{Developing a resident survey for Sapporo (Japan) and Brisbane (Australia)}

This study was part of a larger project comparing Brisbane (Queensland, Australia) and Sapporo (Hokkaidō, Japan). As described elsewhere (Rupprecht \& Byrne 2014a), these cities share similarities and differences that lend well to comparison (e.g. similarities in size, morphology, and geography; differences in location, cultural context, population density and growth forecasts; Table 1). While Sapporo has less greenspace than Brisbane, research has shown that residents form their image of Sapporo by perceiving its greenspaces in daily life (Ueda \& Rupprecht 2014). A comparison provides overviews of human-nonhuman relations across cultural, geographic and population-trajectory-

Table 1. Comparison of cities selected for case study (adopted from Rupprecht \& Byrne 2014a).

\begin{tabular}{|c|c|c|}
\hline & City of Brisbane (LGA) & Sapporo \\
\hline Founded & 1824, city status 1902 & 1868, city status 1922 \\
\hline $\begin{array}{l}\text { Population } \\
\text { (projected) }\end{array}$ & 1,089,743 (2011) (2031: 1,27 million) & 1,936,189 (2013) (2030: 1,87 million) \\
\hline Area & $1,338 \mathrm{~km}^{2}$ & $1,121.12 \mathrm{~km}^{2}$ \\
\hline Pop. density & $814 / \mathrm{km}^{2}$ & $1,699 / \mathrm{km}^{2}$ \\
\hline Peak density & $>5,000 / \mathrm{km}^{2}$ & $>8,000 / \mathrm{km}^{2}$ \\
\hline Climate & Humid subtropical (Cfa) & Humid continental (Dfa) \\
\hline Industry & $\begin{array}{l}\text { Tourism, resources, retail, financial } \\
\text { services, agriculture hub, education }\end{array}$ & $\begin{array}{l}\text { Tourism, retail, IT, agriculture hub, } \\
\text { resources, education }\end{array}$ \\
\hline \multirow[t]{2}{*}{ Greenspace } & Local parks: 3,290 ha (32 m²/capita) & Parks: 2,345 ha (12.3 m²/capita) \\
\hline & All parks: 11840ha (115 m²/capita) & $\begin{array}{l}\text { All greenspace: 5,508 ha (28.9 } \\
\text { m²/capita) }\end{array}$ \\
\hline $\begin{array}{l}\text { Park area } \\
\text { planned }\end{array}$ & $40 \mathrm{~m}^{2} /$ capita, minimum $20 \mathrm{~m}^{2} /$ capita & “No greenspace loss, park renovation" \\
\hline
\end{tabular}


related contexts. However, the comparative research I undertake here does not see the two cities as bounded and given akin to traditional comparative urban studies, but draws loosely upon a relational comparative urban studies approach (Ward 2010). The human-nonhuman entanglements and encounters this paper examines exemplify the openness and relations territorialised in place, even though the methods I use depart from the common qualitative approaches. The scale of the sampling grid (see below) should thus be understood as a result of the ecological study conducted in parallel. Looking at similarities and differences here is an exercise in examining shared relations, not insisting on mutually exclusive contexts. After all, many non-humans encountered traverse the geographic and cultural distances between both sites.

Data collection was undertaken as part of a larger study on informal urban green spaces (IGS) and urban residents' use and perception of such spaces (Rupprecht \& Byrne 2014a; Rupprecht et al. 2015b, 2016). Using a survey served as a way of understanding perceptions, which shape the option space for subsequent planning policies. A postal survey was adopted over door-to-door canvassing due to budget restrictions and to allow respondents to complete the questionnaire at a time convenient for them. A letterbox-drop, reply-paid mail-back questionnaire kit was distributed to a sample of 1,910 households in Brisbane and 1,980 in Sapporo (the small variation resulted from site accessibility). The households were located within a $400 \mathrm{~m}$ radius (easy walking distance) of 121 sampling sites. Questionnaires were only distributed at sites where IGS was located within a $400 \mathrm{~m}$ radius, to maximize potential respondents' IGS interaction. The 121 sampling sites were placed on the intersecting lines of a $10 \mathrm{~km}$ by $10 \mathrm{~km}$ grid centred on the city centres, using a systematic grid sampling design. There was a one-kilometre distance between any two adjacent sampling sites. This allowed covering most of the densely populated area. Additional discussion of survey design is available in prior work (Rupprecht \& Byrne 2014a; Rupprecht et al. 2015b).

Questions asked were part of a larger study on the adult residents' perception and evaluation of IGS (Rupprecht et al. 2015b). The full survey instrument is available online (Rupprecht \& Byrne 2016). This study draws upon a previously unreported sub-set of seven questions in addition to demographic data. Statements on nature's value were derived from La Trobe and Acott's (2000) version of Dunlap's New Environmental Paradigm (NEP) question set (Dunlap et al. 2000), and were modified to specifically address urban nature. Following Sawaki and Kamihogi (1995), respondents wrote down five animals (except pets) they would like to see in their neighbourhood, and five they would not like to see. Pets were excluded because humans make a conscious decision to co-inhabit their home with pets. This open-ended list style was chosen over a Likert-style preference for a given list of animals to accommodate for differences between cities (Bjerke \& Østdahl 2004). Finally, respondents had to balance wildlife protection against possibly necessary restrictions in lifestyle in a question slightly adapted from an earlier survey by Sapporo City (Sapporo Shichō Seisakujitsu Kōhōbu Shimin No Koe O Kiku Ka 2011). The instrument was approved by the human subjects research ethics committee of Griffith University (ENV/28/12/HREC).

Data was analysed in SPSS (v. 21 and 22, OS X) to perform descriptive and inferential statistical tests following standard procedures (Field 2009). Initial analyses indicated that the sample data were not normally distributed (P-P plots, skewness and kurtosis tests). Following Field (2009), I therefore chose non-parametric statistical tests. Bonferroni-corrected Mann-Whitney tests to correct for multiple comparisons were used following Kruskal-Wallis tests to identify educational levels significantly differing from others. The Jonckheere test was used to explore potential trends in effects of different educational attainment levels. Finally, an exact approach for significance using a Monte Carlo simulation was chosen for tests involving age brackets, as this method does not require assuming a normal distribution of the data.

Data on respondents' preference to see or not see animals in their neighbourhood were first cleaned to unify the spelling of animal names, then analysed to identify most frequently mentioned animals. As respondents frequently named both individual species (e.g. blue-tongue lizards, sparrows) and species groups (e.g. lizards, birds), individual species were not consolidated into species groups. Qualitative comments some respondents added to explain their choices were incorporated into the discussion. Preference scores were calculated for animals mentioned more than five times in total by adding up positive mentions (+1) and negative mentions (-1). Highly 
contested animals were defined as those with a difference of more than ten points between preference score and total mentions. Counting each space where residents thought animals or plants should be able to live as one point, scores for general willingness to coexist with plants and animals were calculated (minimum score 0 , maximum score 6 points).

\section{Survey results: coming to grips with nature in the neighbourhood}

A total of 123 valid responses were collected in Brisbane, 163 in Sapporo (response rate: Brisbane $6.4 \%$, Sapporo $8.2 \%$ ). Due to the low response rate, the interpretation of the results demands care to avoid overgeneralization, but the sample is sufficient for the exploratory research undertaken in this paper. Brisbane and Sapporo samples show some differences in respondents' demographic characteristics (Table 2), which have been described in more detail elsewhere (Rupprecht et al. 2015b).

As reported elsewhere (Rupprecht et al. 2015b), respondents valued greenspace in their neighbourhood and generally desired more of it. They did not see themselves as very knowledgeable about local nature (Table 3). Most respondents had what La Trobe and Acott (2000) call proenvironmental value orientations.

Almost all Brisbane respondents stated that they knew the meaning of the word 'biodiversity' (94\%), whereas few had heard the word before but didn't know the meaning (5\%) or didn't know the meaning at all (1\%). In contrast, Sapporo respondents were much less confident: $31 \%$ stated they knew the meaning of the word 'biodiversity', 35\% didn't but had heard the word before, and 33\% didn't know the meaning at all. Most respondents stated that 'to protect urban wildlife and plants, we have to accept restrictions in our lifestyle' (Brisbane 67\%, Sapporo 54\%). In comparison, 16\% (Brisbane) and 32\% (Sapporo) thought 'protecting urban wildlife and plants is important, but not if it means changing our lifestyle', while $16 \%$ and $3 \%$, respectively, stated that 'to enjoy a pleasant and comfortable lifestyle we can't avoid losing urban wildlife and plants'.

Figures 1 (Brisbane) and 2 (Sapporo) show which animals respondents wanted to see most and least in their neighbourhoods. Respondents used the text fields to add information alongside their animal choices that fell largely into two categories, adjectives (in Brisbane) and short, explanatory sentences (in Sapporo). In Brisbane, 'native', 'non-poisonous' and 'beneficial' were used to qualify choices for wanted animals, in contrast to 'feral', 'wild', 'poisonous/venomous', 'biting/diseasecarrying', 'dangerous', 'non-native' and 'introduced' for unwanted animals. Explanatory sentences were limited to 'but humans kill them all' (emphasis by the respondent, talking about tree snakes and other snakes) for wanted animals and 'any that don't like me' for unwanted animals.

In Sapporo, short explanatory sentences were more common than adjectives. For wanted animals, respondents occasionally excluded certain species (e.g. 'birds except crows') and one expressed he would welcome cuckoos which 'were common in the past'. For unwanted animals, respondents gave descriptions diverging from species categories: 'animals with no affection for their owners' (but clarifying 'though it's not the animal's fault'), 'animals causing harm to humans' (but clarifying 'they should still be protected as much as possible'), 'animals that do not belong/are out of place', and 'abandoned pets'. Reasons why certain animals were unwanted included: 'cats are scary', 'Echinococcus' (a tapeworm transmitted via fox faeces), 'they will be killed when found, it's sad' (about bears and deer), 'they destroy the ecosystem of Japanese animals' (about non-native species), and 'I want them to live a bit more in the mountains'. In addition, the adjectives 'dangerous', 'large', 'wild' and 'feral' were used infrequently.

Figures 3 (animals) and 4 (plants) show to which degree respondents thought urban spaces were most appropriate for non-humans to live in. Overall, Sapporo respondents ranked spaces lower, with differences between the cities more pronounced for animals.

\section{Influence of sex, income, education and age}

As noted above, due to the low response rate, the interpretation of the following results demands care to avoid overgeneralization. All effects and significant differences are reported at a statistical significance level of $p<.05$. No statistically significant differences were found in either city between 
Table 2. Sample population characteristics and comparison with census data (adopted from Rupprecht et al. 2015b).

\begin{tabular}{|c|c|c|c|c|c|c|}
\hline \multirow[t]{2}{*}{ Variables } & & \multicolumn{2}{|c|}{ Brisbane (LGA) } & \multicolumn{2}{|c|}{ Sapporo } & \multirow[t]{2}{*}{$\mathbf{p}^{*}$} \\
\hline & & City & Sample & City & Sample & \\
\hline Age & Median & 34 & 54 & 45 & 58 & $<0.05$ \\
\hline Sex & Females (\%) & 50.7 & 62.7 & 53.0 & 53.2 & n. s. \\
\hline $\begin{array}{l}\text { Education } \\
\text { (in \%) }\end{array}$ & $\begin{array}{c}\text { Did not finish high school } \\
\text { High school } \\
\text { University }\end{array}$ & $\begin{array}{l}10.5 \\
25.1 \\
30.7\end{array}$ & $\begin{array}{c}2.5 \\
18.6 \\
78.9\end{array}$ & $\begin{array}{l}11.0 \\
36.6 \\
32.2\end{array}$ & $\begin{array}{r}3.8 \\
42.5 \\
53.8\end{array}$ & $<0.001$ \\
\hline $\begin{array}{l}\text { Income }{ }^{\star *} \\
\text { (annual house- } \\
\text { hold, in \%) }\end{array}$ & $\begin{array}{c}\text { Less than } \$ 25 \mathrm{k} / ¥ 2 \text { million } \\
\$ 25 \mathrm{k}-\$ 50 \mathrm{k} / ¥ 2-4 \text { million } \\
\$ 50 \mathrm{k}-\$ 75 \mathrm{k} / ¥ 4-6 \text { million } \\
\$ 75 \mathrm{k}-\$ 100 \mathrm{k} / ¥ 6-8 \text { million } \\
\$ 100 \mathrm{k}-\$ 125 \mathrm{k} / ¥ 8-10 \text { million } \\
\$ 125 \mathrm{k}-\$ 150 \mathrm{k} / ¥ 10-12.5 \text { million } \\
>\$ 150 \mathrm{k} / ¥ 12.5 \text { million } \\
\text { Do not wish to answer }\end{array}$ & $\begin{array}{l}18.1 \\
14.7 \\
15.9 \\
13.1 \\
10.4 \\
11.5 \\
16.3\end{array}$ & $\begin{array}{c}5.8 \\
13.2 \\
13.2 \\
13.2 \\
9.1 \\
13.2 \\
21.5 \\
10.70\end{array}$ & $\begin{array}{l}21.7 \\
32.2 \\
19.0 \\
9.8 \\
6.2 \\
3.6 \\
3.4\end{array}$ & $\begin{array}{l}11.2 \\
34.2 \\
15.5 \\
14.3 \\
6.8 \\
2.5 \\
2.5 \\
13.0\end{array}$ & $<0.001$ \\
\hline $\begin{array}{l}\text { Housing } \\
\text { (in \%) }\end{array}$ & $\begin{array}{l}\text { House (detached, duplex, } \\
\text { town/row/terrace house) with garden } \\
\text { House (detached, duplex, } \\
\text { town/row/terrace house) without } \\
\text { garden } \\
\text { Apartment or unit with shared } \\
\text { greenspace } \\
\text { Apartment or unit without shared } \\
\text { greenspace }\end{array}$ & & $\begin{array}{c}81.3 \\
2.4 \\
10.6 \\
5.7\end{array}$ & & $\begin{array}{l}54.7 \\
4.3 \\
9.9 \\
31.1\end{array}$ & $<0.001$ \\
\hline
\end{tabular}

\footnotetext{
* Significant difference level between Brisbane and Sapporo questionnaire sample means using Mann-Whitney U tests.

** Note: Brisbane City income categories do not correspond exactly with the categories used in the table (vary between $+\$ 600$ for lowest category and $+\$ 6000$ for highest category).

Sources: Australian Bureau of Statistics, Sapporo City Statistics Department.
}

women and men for biodiversity knowledge, opinion about wildlife-lifestyle balance or score for general willingness to co-exist with animals and plants (the sum of appropriate places to live). Wanted, unwanted and contested animals were almost identical in both cities between sexes (not statistically tested). Similarly, income had no significant effect on these results.

Biodiversity knowledge significantly increased with education only in Sapporo, while education had no effect on opinion about wildlife-lifestyle balance in either city. In Sapporo, general 
Table 3. Means of residents' views on close greenspace, their knowledge about nature, and disposition towards urban nature (adopted from Rupprecht et al. 2015b).

\begin{tabular}{|c|c|c|c|c|}
\hline Topic & Questions asked (1=str. agree, 5=str. disagree) & Brisbane & Sapporo & p* \\
\hline $\begin{array}{l}\text { Greenspace in } \\
\text { neighbourhood }\end{array}$ & $\begin{array}{c}\text { There should be more green space in my neighbourhood. } \\
\text { The green space in my neighbourhood is very important to } \\
\text { me. }\end{array}$ & $\begin{array}{l}2.11 \\
1.68\end{array}$ & $\begin{array}{l}2.40 \\
1.85\end{array}$ & $\begin{array}{l}<0.01 \\
<0.05\end{array}$ \\
\hline $\begin{array}{l}\text { Knowledge about } \\
\text { neighbourhood nature }\end{array}$ & $\begin{array}{l}\text { I know a lot about the wild plants in my neighbourhood. } \\
\text { I know a lot about the wild animals in my neighbourhood. } \\
\text { I know a lot about the birds in my neighbourhood. }\end{array}$ & $\begin{array}{l}3.18 \\
2.84 \\
2.75\end{array}$ & $\begin{array}{l}3.71 \\
3.67 \\
3.66\end{array}$ & $\begin{array}{l}<0.001 \\
<0.001 \\
<0.001\end{array}$ \\
\hline $\begin{array}{l}\text { Attitude towards urban } \\
\text { nature (derived from } \\
\text { NEP) }\end{array}$ & $\begin{array}{l}\text { Urban nature has value within itself, regardless of any value } \\
\text { humans may place on it. } \\
\text { We have an obligation to preserve urban nature for future } \\
\text { generations. } \\
\text { I would contribute money to preserve urban nature. } \\
\text { Urban animals and plants have as much right as humans to } \\
\text { exist. }\end{array}$ & $\begin{array}{l}1.60 \\
2.51 \\
2.04\end{array}$ & $\begin{array}{l}1.66 \\
2.92 \\
2.31\end{array}$ & $\begin{array}{r}\text { n.s. } \\
<0.001 \\
<0.01\end{array}$ \\
\hline
\end{tabular}

* Significant difference level between Brisbane and Sapporo sample means using Mann-Whitney $U$ tests.

willingness to coexist with plants was affected by education level $(H(3)=12.228)$. Bonferronicorrected (thus reported at a $p<.0167$ level of significance) Mann-Whitney tests showed that respondents who did not complete high school had a significantly lower score than all other respondents. In Brisbane, both general willingness to coexist with plants $(H(3)=9.302)$ and animals $(H(3)=9.285)$ were significantly affected by education level. Jonckheere's test revealed that with rising education level scores moderately increased for both animals $(\mathrm{J}=2737, z=2.89, r=.27)$ and plants $(\mathrm{J}=2761, \mathrm{z}=3.00, \mathrm{r}=.28$ ).

Age had no effect on biodiversity knowledge, but different age brackets showed significantly different opinion regarding wildlife-lifestyle balance in Sapporo $(p<.01$ based on Monte Carlo simulation with 1,000,000 samples). Increasing age (in years) also had a significant, moderate negative effect on willingness to coexist with plants in Sapporo $\left(r_{s}=-.29\right)$ and willingness to coexist with animals in Brisbane $\left(r_{s}=-.37\right)$. All three age-related effects exhibited a similar pattern: favouring wildlife protection over lifestyle (Sapporo) as well as willingness to coexist with plants (Sapporo) and animals (Brisbane) peaked in the 30 to 40 and 40 to 50 years age bracket to fall off with increasing age. The $80+$ year age bracket in Sapporo represented the only exception, as its opinion about wildlife-lifestyle balance was strongly in favour of wildlife protection and more similar to the 30 to 50 years age bracket.

\section{Pathways to coexistence: moving from conflict to encounters on neutral ground}

Residents' familiarity with the meaning of the word 'biodiversity' in Sapporo was similar to levels reported in an earlier survey in Sapporo (Sapporo Shichō Seisakujitsu Kōhōbu Shimin No Koe O Kiku Ka 2011) and slightly lower than the European average of 38\% in 2010 (European Commission 2010). In comparison, familiarity was extremely high (94\%) in Brisbane, but no data are available for Australia that would allow a direct comparison. The high familiarity could be a result of public debates around wildlife conflicts, in which nativeness plays a prominent role (Trigger \& Head 2010). In contrast, the difference between the cities was far less pronounced in residents' attitudes towards nature and their opinion about wildlife protection and human lifestyle (Rupprecht et al. 2015b). This result is also reflected in a previous analysis of attitudes towards urban nature, where Brisbane and Sapporo respondents showed only limited differences in the value they attribute to urban nature (Rupprecht et al. 2015b). This could suggest that 'technical' knowledge about biodiversity is at best a weak mediator of attitudes towards wildlife. Moreover, these results do not reflect the pronounced difference in 
Wanted, unwanted and contested animals in Brisbane

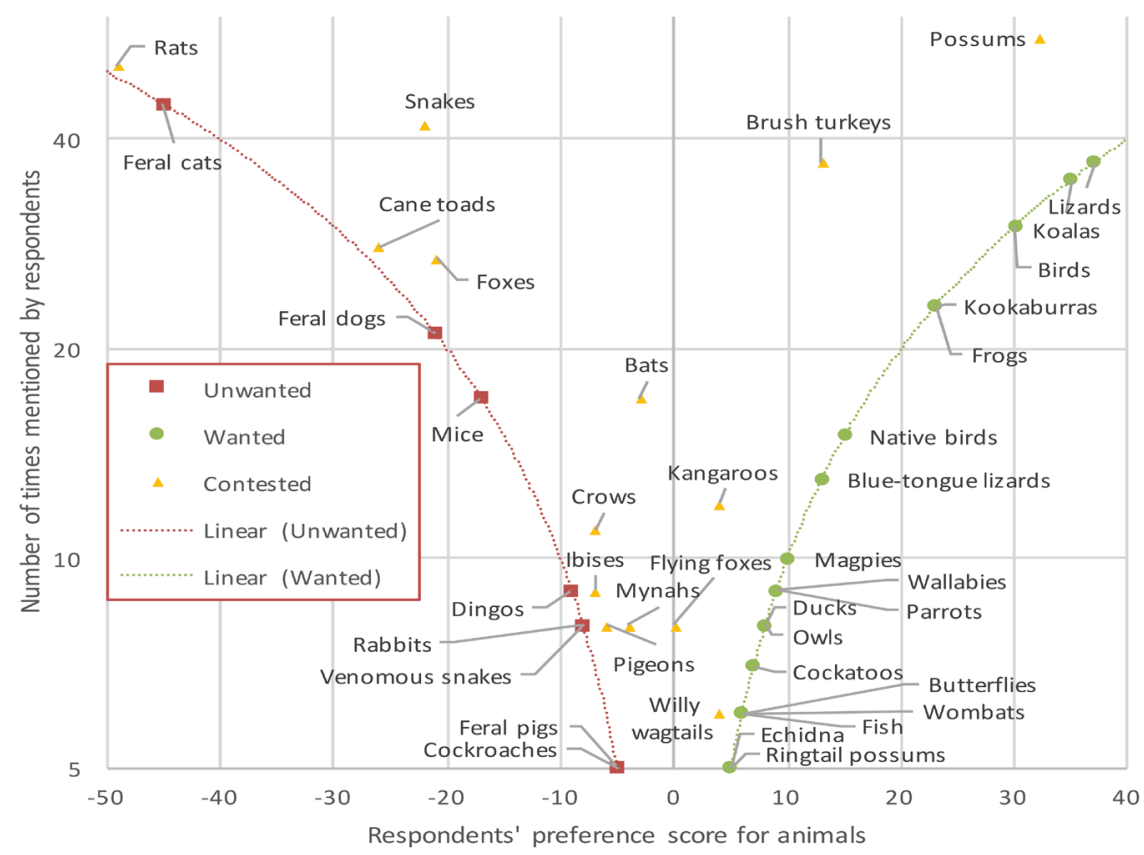

Fig. 1. Brisbane respondents' preferences for animals in their neighbourhood.

Wanted, unwanted and contested animals in Sapporo

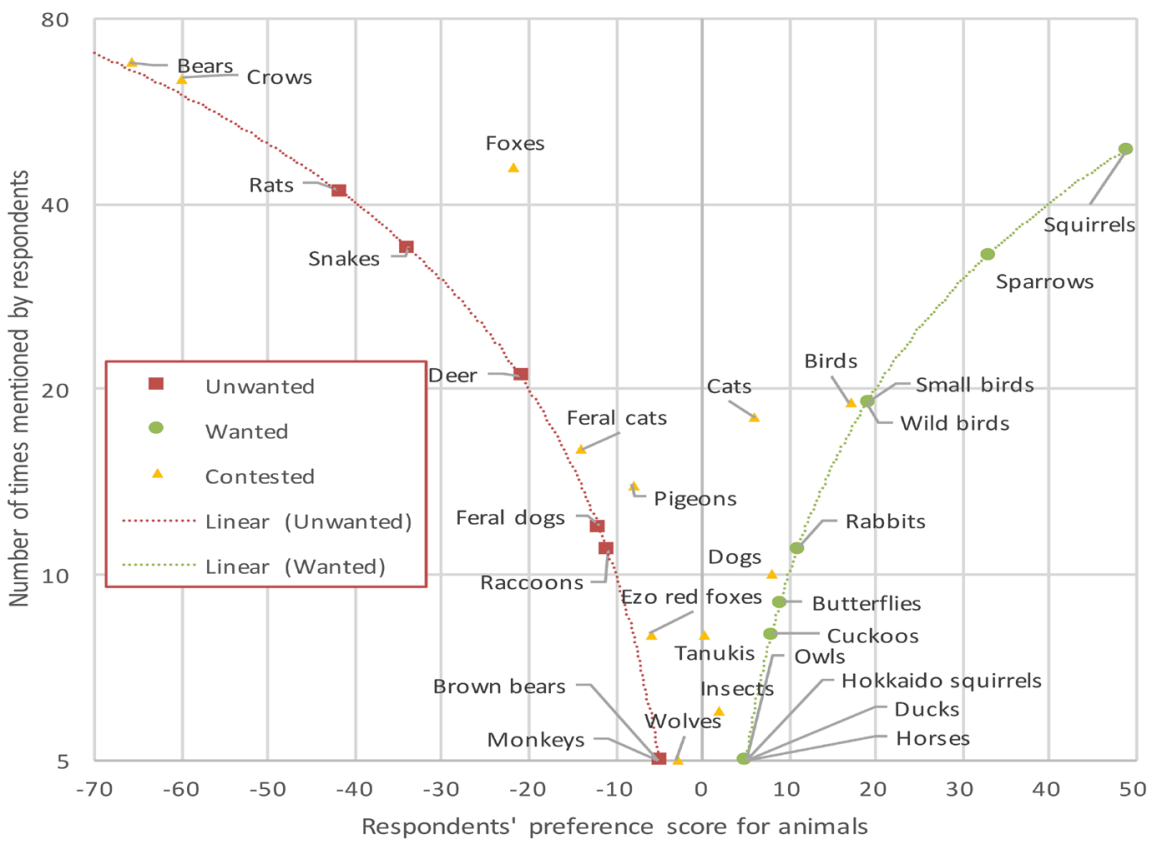

Fig. 2. Sapporo respondents' preferences for animals in their neighbourhood. 
attitudes one might expect from previous research by Kellert $(1991,1993)$, who reported less ethical or ecological concern for nature and wildlife among Japanese citizens compared to citizens of the United States of America or Germany. However, the low response rate in this study limits the degree to which these results can be generalised.

Sex did not influence opinion about wildlife-lifestyle balance or score for general willingness to coexist. It seemed similarly unimportant for respondents' attitude toward particular animals. These results diverge from previous studies, which reported gender as a significant influence factor (Bjerke et al. 1998a, 1998b; Bjerke \& Østdahl 2004; Almeida et al. 2014; Borgi \& Cirulli 2015).

\section{Where do you think animals should be able to live?}

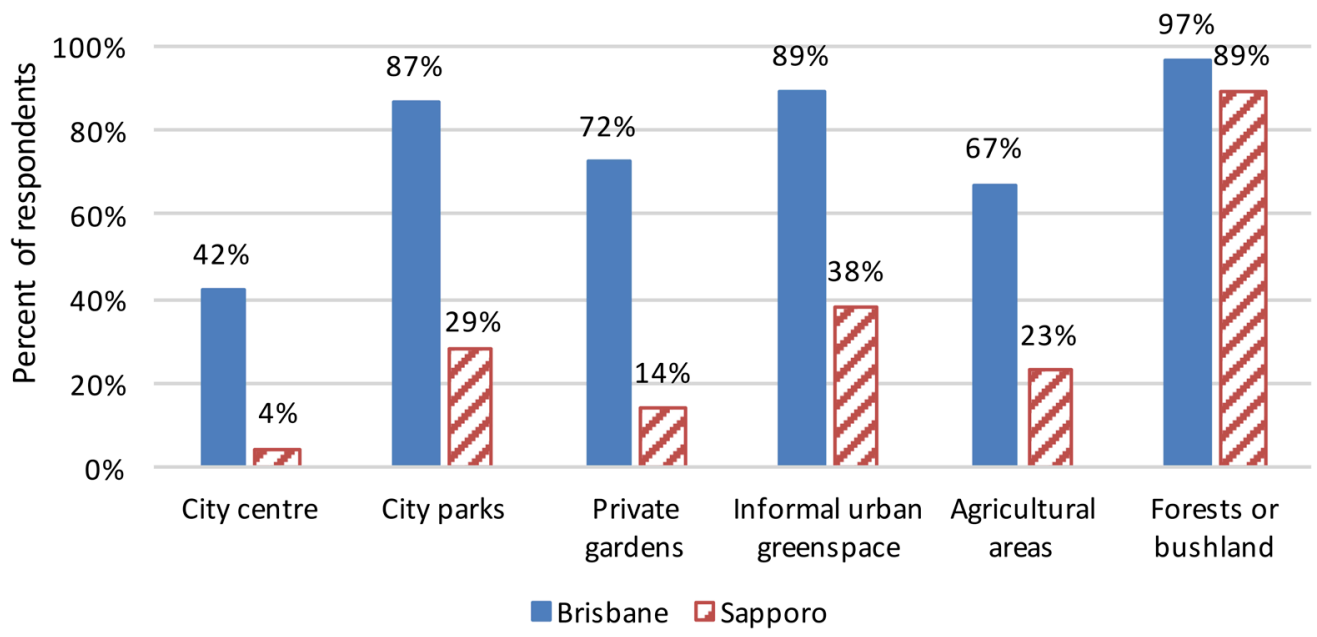

Fig. 3. Brisbane and Sapporo respondents' perceived places of belonging for animals.

\section{Where do you think should wild plants be able to live?}

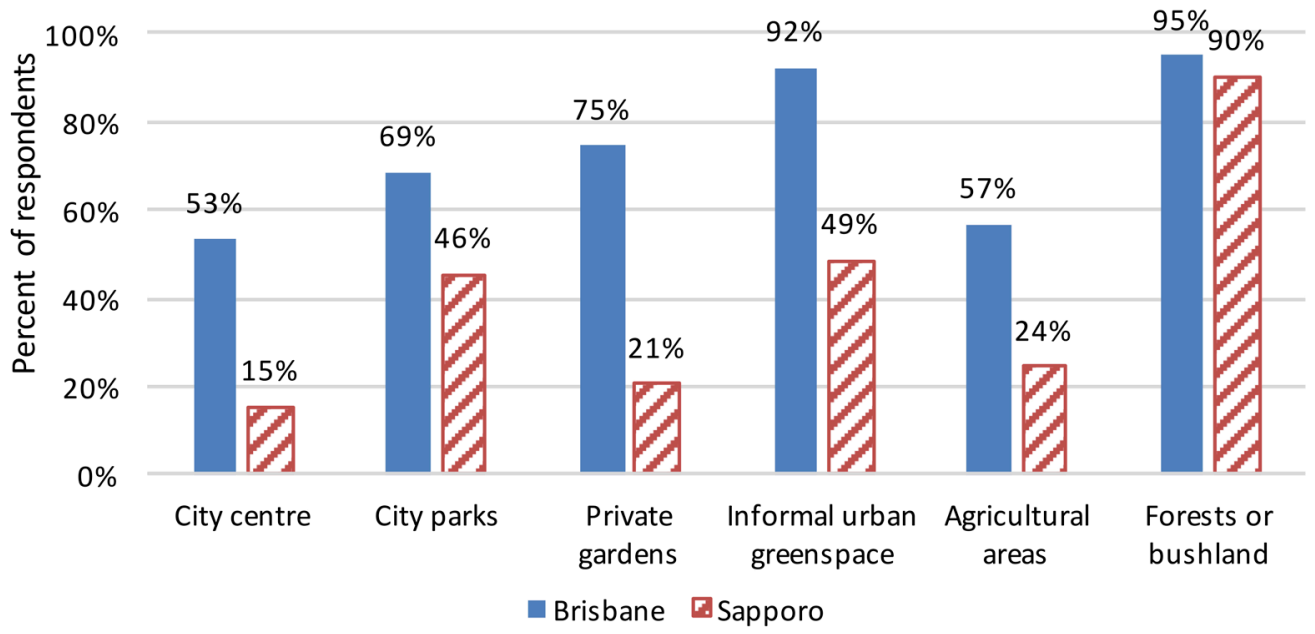

Fig. 4. Brisbane and Sapporo respondents' perceived places of belonging for plants. 
Education increased willingness to coexist to some degree, as has been shown for species preferences (Bjerke \& Østdahl 2004). This suggests there may be an argument to be made for educational campaigns to foster interspecies relationships. However, for non-charismatic species such efforts may not always produce the desired effect. In a study on students' perceptions of blacktailed prairie dogs, Fox-Parrish and Jurin $(2008,7)$ reported students' thoughts revealed 'little to no concern for prairie dogs or their well-being' - despite numerous classroom- and field-based educational activities.

Questions remain about the observed trend towards higher willingness to coexist with younger age. Does this result suggest a shift in values over generations? Alternatively, do individuals' attitudes toward animals change over their lifetime? For the latter, Bjerke and Østdahl (2004) found a significant but minute effect for individual species preferences. Yet data in this area remains scarce, and further research could help planners take such aspects into account if necessary.

\section{Global and local animals, contested urban space}

As we enter the Anthropocene, the animals and plants we encounter in cities are becoming increasingly similar (Wittig \& Becker 2010; Lososová et al. 2012), though urbanisation can also drive local increases in species richness (Ellis et al. 2012). While the differences in animals named in the two cities in this study were still larger than the similarities, four groups of animals characterised by two distinctions emerged - local and global, wanted and unwanted animals. To understand respondents' preferences for sharing their neighbourhood with particular species, it helps to look at the species in each group and think about how urban space and its human order is contested by animals. Globally wanted animals (birds and especially small birds, butterflies) and locally wanted animals (squirrels) rarely contest our use of cities, even if the reason for this could be their scarcity and endangered status (lizards, koalas). In contrast, globally unwanted animals (e.g. rats, foxes, snakes, crows, feral dogs and cats as well as pigeons) are those who defy our considerable efforts to exterminate them. They do well living alongside us in cities, despite our antipathy (Lambert 2016), and prove human claims of dominance and control wrong. Locally unwanted animals (e.g. bears, deer, dingos and monkeys) draw our attention to the contested and shifting nature of urban boundaries, especially in the absence of material symbols in the form of city walls. Bears visiting Sapporo from the surrounding mountain forests are one such example where our dominance over urban space is threatened - occasionally, authorities are forced to declare local parks declared off-limits for residents (Sapporo Kankyōkyoku Midori No Suishinbu 2013). Their size may also explain why they featured more prominently than insects, which were comparatively underrepresented in residents' preferences. The smaller the organism, the less powerful to challenge us we may perceive it to be, or else we would be forced to concede defeat to microorganisms immediately. For Sapporo, linguistics could provide another clue. The Japanese word for animal used in the survey (動物, dōbutsu) can be interpreted not to include insects (虫, mushi).

In Brisbane, nativeness played a role almost completely absent in Sapporo. Non-native animals (rabbits, cane toads, feral cats) appear to violate not only a physical, but also a place-specific ideological boundary by trespassing into spaces where they are perceived not to belong. This phenomenon has been reported and discussed previously (Trigger \& Head 2010). Yet some nonnative animals enjoy wide acceptance (cattle, sheep, chickens), while others gain little sympathy from their native status (snakes, bats, dingos). The ideological boundaries of nativeness are thus as contested and shifting as their material urban counterparts (Trigger et al. 2008).

Qualifying adjectives (e.g. feral, wild, dangerous, large, scary) in the qualitative comments from respondents further support the idea that respondents' preferences for animals are related to how animals contest urban space. However, some comments also demonstrate empathy with the plight of urban animals. Respondents expressed sadness about interspecies conflict and harm done to animals by humans, or insisted on animals' protection as a priority alongside preventing harm to humans. Others emphasized the concept of animals 'out of place', of not-belonging, for example voicing their preference for bears to live 'a bit more in the mountains'. Such comments suggest that urban areas that are less firmly occupied as human space in our imagination may point toward ways for conciliation. 


\section{Spaces of belonging - informal green spaces as territories of encounter?}

If our conflict with animals and plants arises from contested space and dominance, where in the city do non-humans belong? Where are we willing to relax our claims of dominance? After arguably nonurban spaces such as forests or bushlands, respondents chose IGS as the urban spaces they thought animals and wild plants should be able to live in. Could IGS be one potential path leading to morethan-human cities? Recently, scholars have begun looking toward such urban wildscapes (Jorgensen \& Keenan 2012) and terrain vague (Barron \& Mariani 2013) as loose spaces (Franck \& Stevens 2007), unclaimed territories (Cloke \& Jones 2005) where normal restrictions and expectations hold less power, as liminal nature that doesn't 'belong' to humans (Rupprecht et al., 2015b). Neither formally recognized by governing institutions or property owners as greenspace designated for agriculture, forestry, gardening, recreation or environmental protection, the vegetation and fauna in IGS is not managed for any of these purposes (Rupprecht \& Byrne 2014a). As a result, IGS can provide habitat and support urban biodiversity (Rupprecht et al. 2015a), though its ecology as a novel ecosystem is distinct from historic ecosystems or nature reserves (Hobbs et al. 2006). Unclaimed, IGS may provide 'territories of encounter'1 with an uniquely urban ecosystem of undomesticated plants and animals, an opportunity for a being-together from childhood and teen age (Rupprecht et al. 2016) to adulthood (Rupprecht \& Byrne 2014b; Rupprecht et al. 2015b).

Urban residents can perceive these spaces and the lack of control both positively and negatively (Rink \& Emmrich 2005; Qviström 2012; Rupprecht et al. 2015b). However, a more tolerant, sharing approach of coexistence in the city may require turning away from the bucolic ideal and intent to improve the users' health and morals that underlie traditional green spaces (Rosenzweig \& Blackmar 1992; Baldwin 1999). As Nohl $(1990,62)$ argues:

"Nature, mostly self-regulating, and self-determinedly acting users are the ones finding their way to a conciliatory coexistence in these dysfunctional-useless spaces. The realization giving extra weight to this utopian moment is that this aesthetic appearance may be a glimpse at a possible future alternative, rather than an unattainable ideal: the aesthetic joy of urban wasteland has its origins in the fact that this wasteland, as a devastated (as everyone can see) part of the contemporary city, is still showing self-organizing life, and is thus able to symbolize a better future. [...] Because in the interplay [of human use and the developmental processes of nature] the aesthetic-symbolically experienced 'whole nature', the partner-relationship between humans and nature, contrasts markedly with the aggressive dominance over nature omnipresent elsewhere in the city. [...] The aesthetic joy the observer experiences when looking at such open spaces can be explained by the fact that he has discovered an actually possible image of a more conciliatory world." (translated from German)

In contrast to nature reserves or parks, the rules of our encounter with animals and plants in these territories of encounter are not pre-negotiated, not controlled by park rangers or fences. This can open up possibilities for exploration, renegotiation and possibly even reconfiguration of our mutual entanglement. According to Nohl $(1990,65)$, IGS could thus provide the potential for a 'provisional arrangement' that leaves room for both emancipated greenspace users and nature, because 'it disciplines neither people in their actions nor nature in its development'.

Does IGS then undermine the dualism of urban and nature, or on the contrary reinforce it? As previous work shows (Rupprecht et al. 2015b), residents seemed to both value the breakdown of clear demarcations between intentional green space and struggle with its informality. On an individual level of engagement, I therefore argue encounters with IGS can prompt residents to rethink urban nature. At this point, critical readers might ask: should IGS be endorsed simply because it is (sometimes) easy for (some) people to accept? Does not shared urban living demand more than this? These questions can be understood as an issue of what is right or ideal versus concrete progress (even if slow). Non-violent coexistence is by no means sufficient as a final goal for human-non-human co-inhabitation to strive for. Yet at the moment, systematic suppression and institutionalised killing still characterises all too many human-non-human relations (Hillier \& Byrne 2016). Establishing of neutral zones where non-violent coexistence is tolerated or even encouraged would therefore be a meaningful and substantial step towards 'making kin, not cities' (Houston et al. 2017), particularly because the difficulties inherent in even such small advances are something 
urban planning and political ecology scholars have repeatedly documented. That said, the real challenges lie beyond the individual and at the planning and institutional level, as outlined below.

\section{IGS in planning and management: opportunities and challenges}

As data from Sapporo and Brisbane shows, IGS can account for $14 \%$ of total urban green space of cities (Rupprecht \& Byrne 2014a), making it an important element of the urban landscape. As discussed elsewhere (Rupprecht et al. 2015b; Rupprecht 2017), planners could help making the territories of encounter more accessible by reducing barriers or mapping such spaces, but a number of constraints (liability issues, private ownership, historical/political/financial constraints) limit planner's ability for direct interventions. Therefore, participative management approaches could help to avoid outcomes like the New York High Line, where IGS was simply converted into neoliberal green space, demonstrating how the fascination and promise of engaging with 'wild' nonhumans can be reduced to its aesthetic appeal in the name of capitalism (Millington 2015). In a way, the High Line thus presents an extreme case of a carefully landscaped space posing as IGS, a space that is precisely so easy to accept (and thus preferred by its visitors) because benches, pathways and design provide clear demarcations. On the High Line, contrary to IGS, wildness is performed, encounters are pre-negotiated, provisional arrangements are no longer possible, nature is disciplined. To what degree can the urban-nature dualism then be overcome through planning and management?

One possible approach is to facilitate participatory management of IGS (Rupprecht 2017), thereby allowing residents to explore their individual taste for coexistence, rather than planners setting the ground rules in advance. Planners can draw upon the results of this study which suggest urban residents' willingness to coexist with wildlife is influenced by species, geography, cultural factors, education and age (but not income or sex). Mapping wanted and unwanted animals (Figure 1, 2) could help planners to focus management efforts on locally most prominent species, offering a better insight into residents' preferences than current contestation-focused wildlife conflict reports. Understanding where residents' preferences overlap or differ from municipal conservation strategies could identify potential synergies or problems. Small-scale maps could help tailor management towards individual neighbourhoods. Tracking such information over time may also allow planners and wildlife managers to intervene before conflicts escalate. Green space design could draw on residents' species preferences, for example by retrofitting features that attract birds or butterflies (e.g. wildflower meadows). Similarly, knowing where residents think animals and wild plants should be able to live (and where not) could allow managing wildlife interactions differently for the city centre, parks or IGS. Cultural factors such as the different role of nativeness may help planners to understand which points to emphasize in communicating with residents in conservation or wildlife management projects. Finally, planners and developers could aim to design projects for particular age groups (e.g. retirement housing or child care centres) by taking into account different age groups' species preferences and general willingness to coexist with wildlife. Recent work by Houston and colleagues (2017) further discusses how planning theory might contribute.

\section{Conclusion and directions for further research}

In this study, I attempt to answer calls from scholars to look for paths towards more-than-human cities. Using a quantitative approach, I reported results from an exploratory survey in Brisbane, Australia, and Sapporo, Japan, which asked residents about their willingness to coexist with wildlife, their preferences for undomesticated animals in their neighbourhood, and perceived places of belonging for animals and plants. While the low response rate of the study limits the extent to which these results can be generalised, the sample used was sufficient for this exploratory study. Geographical and cultural context alongside respondents' educational attainment and age influenced their willingness to coexist with wildlife, but not sex and income. Mapping respondents' preferences for animals in their neighbourhood, identified global and local as well as wanted and unwanted groups of animals. These categories differed in the way the animals contested the human notions of control over urban space. Most respondents chose IGS as the space where animals and wild plants should be living 
in the city after forests and bushland. Drawing upon recent theoretical and empirical work by scholars suggesting that IGS is less restricted by expectations for human control, I proposed IGS as the territories of encounter and one potential path to more-than-human cities. In particular, I argued with Nohl (1990) that these spaces can offer 'provisional arrangements' that allow us to engage with nonhumans in a conciliatory way. Finally, I discussed some ways planners could work with IGS and quantitative methods of understanding interspecies interactions to improve planning and management.

This study has helped to identify a number of directions for further research. First, this study has focused on animals, leaving open the question whether plants are similarly perceived as challenging the human control of space. Second, recent history has seen a surge in human-animal related literature, catalogued by the excellent Animal Studies Living Bibliography (n.d.), which exceeds the space of a review as part of a paper introduction and merits one or more dedicated reviews to complement the two previous ones by $\operatorname{Buller}(2014,2015)$. Third, researchers should investigate what role factors that fell outside of the scope of this study might play in mediating residents' willingness to coexist with animals: urban density; the presence of, access to and use of greenspace; if people's values influenced their decisions about where they live; whether living in a particular place or particular human-animal interactions have altered their views; whether particular animals are viewed as belonging in particular places; and whether observed or perceived animal presence in the neighbourhood influence residents' answers. Fourth, examining pet-mediated human-nonpet relations might shine light on their possible role as either conflict mediators or (as observed in pet-wildlife interactions) a source of additional conflict. Fifth, not limiting the number of animals identified by respondents as wanted or unwanted could help identify individual variations in willingness to coexist on the human side, and provide insights into whether the patterns of preference for certain species among 'animal lovers' and those less so-inclined. Finally, the biggest challenge remains: to turn the direction of inquiry around and find a way to discern how non-human preferences drive where, how, and whom they share or contest spaces.

\section{Notes}

${ }^{1}$ The term 'territories of encounter' was not included in the survey instrument and is offered here as a provocative reframing of space often seen as derelict or wasted.

\section{Acknowledgements}

I am deeply grateful: to Yumi Nakagawa for invaluable help with data collection, the Japanese survey instrument and data entry, to Kumiko Nakagawa for assistance with the Japanese survey instrument and Japanese qualitative responses, to Jason Byrne for guidance and friendship throughout the project, to Hirofumi Ueda for assistance with the Japanese survey instrument and data collection in Sapporo, to Bill Metcalf for advice on research design, to Ruth Potts for helpful comments on the manuscript, to all respondents for participating and making this study possible, to the Association of American Geographers Urban Geography Specialty Group for awarding an earlier version of this paper the 2016 Dissertation Award, and to reviewers for their helpful comments. This research was supported by Griffith University and by the FEAST Project (No. 14200116), Research Institute for Humanity and Nature (RIHN).

\section{References}

Adams, C. E. (2012) Urban wildlife management. $2^{\text {nd }}$ ed. CRC Press, Boca Raton.

Almeida, A., Vasconcelos, C. \& Strecht-Ribeiro, O. (2014) Attitudes toward animals: a study of Portuguese children. Anthrozoös 27(2) 173-190. https://doi.org/10.2752/175303714X13903827487403

Anderson, K. (1997) A walk on the wild side: a critical geography of domestication. Progress in Human Geography 21(4) 463-485. https://doi.org/10.1191/030913297673999021

Animal Studies Living Bibliography (n.d.) The living bibliography of animal studies. $<$ http://Www.Ibanimalstudies.org.uk/index.php?title=Main Page>. 27.10.2017. 
Baldwin, P. C. (1999) Domesticating the street: the reform of public space in Hartford, 1850-1930. Ohio State University Press, Columbus, $\mathrm{OH}$.

Barron, P. \& Mariani, M. (eds.) (2013) Terrain vague. Routledge, London.

Barua, M. (2014) Volatile ecologies: towards a material politics of human-animal relations. Environment and Planning A 46(6) 1462-1478. https://doi.org/10.1068/a46138

Barua, M., Bhagwat, S.A. \& Jadhav, S. (2013) The hidden dimensions of human-wildlife conflict: health impacts, opportunity and transaction costs. Biological Conservation 157 309-316. https://doi.org/10.1016/j.biocon.2012.07.014

Belaire, J. A., Westphal, L. M., Whelan, C. J. \& Minor, E. S. (2015) Urban residents' perceptions of birds in the neighborhood: biodiversity, cultural ecosystem services, and disservices. The Condor 117(2) 192-202. https://doi.org/10.1650/CONDOR-14-128.1

van den Berg, M., Wendel-Vos, W., van Poppel, M., Kemper, H., van Mechelen, W. \& Maas, J. (2015) Health benefits of green spaces in the living environment: a systematic review of epidemiological studies. Urban Forestry \& Urban Greening 14(4) 806-816. https://doi.org/10.1016/j.ufug.2015.07.008

Bjerke, T., Ødegårdstuen, T. S. \& Kaltenborn, B. P. (1998a) Attitudes toward animals among Norwegian adolescents. Anthrozoös 11(2) 79-86. https://doi.org/10.2752/089279398787000742

Bjerke, T., Ødegårdstuen, T. S. \& Kaltenborn, B. P. (1998b) Attitudes toward animals among Norwegian children and adolescents: species preferences. Anthrozoös 11(4) 227-235. https://doi.org/10.2752/089279398787000544

Bjerke, T. \& Østdahl, T. (2004) Animal-related attitudes and activities in an urban population. Anthrozoös 17(2) 109-129. https://doi.org/10.2752/089279304786991783

Bjerke, T., Østdahl, T. \& Kleiven, J. (2003) Attitudes and activities related to urban wildlife: pet owners and non-owners. Anthrozoös 16(3) 252-262. https://doi.org/10.2752/089279303786992125

Bolund, P. \& Hunhammar, S. (1999) Ecosystem services in urban areas. Ecological Economics $29293-$ 301. https://doi.org/10.1016/S0921-8009(99)00013-0

Bordenstein, S. R. \& Theis, K. R. (2015) Host biology in light of the Microbiome: ten principles of holobionts and hologenomes. PLoS Bio/13(8) e1002226. https://doi.org/10.1371/journal.pbio.1002226

Borgi, M. \& Cirulli, F. (2015) Attitudes toward animals among kindergarten children: species preferences. Anthrozoös 28(1) 45-59. https://doi.org/10.2752/089279315X14129350721939

Brown, T. \& Cummins, S. (2013) Intervening in health: the place of urban green space. Landscape and Urban Planning 118 59-61. https://doi.org/10.1016/j.landurbplan.2013.06.003

Buller, H. (2014) Animal geographies I. Progress in Human Geography 38(2) 308-318. https://doi.org/10.1177/0309132513479295

Buller, H. (2015) Animal geographies II Methods. Progress in Human Geography 39(3) 374-384. https://doi.org/10.1177/0309132514527401

Byrne, J. (2011) The human relationship with nature: rights of animals and plants in the urban context. In Douglas, I., Goode, D., Houck, M. C. \& Wang, R. (eds.) The Routledge handbook of urban ecology (vols 1-6), 63-73. Routledge, London.

Calvino, I. (2013) Invisible cities. Houghton Mifflin Harcourt, Boston.

Cloke, P. \& Jones, O. (2005) ‘Unclaimed territory': childhood and disordered space(s). Social \& Cultural Geography 6(3) 311-333. https://doi.org/10.1080/14649360500111154

Davison, A. (2006) Turbulent times for urban nature: Conserving and re-inventing nature in Australian cities. Australian Zoologist 33(3) 306-314. https://doi.org/10.7882/AZ.2006.004

van Dooren, T. \& Rose, D.B. (2012) Storied-places in a multispecies city. Humanimalia: A Journal of Human/Animal Interface Studies 3(2) 1-27.

Dunlap, R. E., van Liere, K. D., Mertig, A. G. \&Jones, R. E. (2000) New trends in measuring environmental attitudes: Measuring endorsement of the new ecological paradigm: a revised NEP scale. Journal of Social Issues 56(3) 425-442. https://doi.org/10.1111/0022-4537.00176

Dunn, R. R., Gavin, M. C., Sanchez, M. C. \& Solomon, J. N. (2006) The pigeon paradox: dependence of global conservation on urban nature. Conservation Biology 20(6) 1814-1816. https://doi.org/10.1111/j.1523-1739.2006.00533.x

von Döhren, P. \& Haase, D. (2015) Ecosystem disservices research: a review of the state of the art with a focus on cities. Ecological/ndicators 52490-497. https://doi.org/10.1016/j.ecolind.2014.12.027

Ellis, E. C., Antill, E. C. \& Kreft, H. (2012) All Is not loss: plant biodiversity in the Anthropocene. PLOS ONE 7(1) e30535. https://doi.org/10.1371/journal.pone.0030535

Enari, H. \& Suzuki, T. (2010) Risk of agricultural and property damage associated with the recovery of Japanese monkey populations. Landscape and Urban Planning 97(2) 83-91.

https://doi.org/10.1016/j.landurbplan.2010.04.014 
European Commission (2010) Attitudes of Europeans towards the issue of biodiversity, No. 290. $<$ http://ec.europa.eu/public_opinion/flash/fl_290_en.pdf> 27.10.2017.

Field, A. (2009) Discovering statistics using SPSS. Sage Publications, London.

Foster, J. \& Sandberg, L.A. (2010) Friends or foe? Invasive species and public green space in Toronto. Geographical Review 94(2) 178-198. https://doi.org/10.1111/j.1931-0846.2004.tb00166.x

Fox-Parrish, L. \& Jurin, R. R. (2008) Students' perceptions of a highly controversial yet keystone species, the black-tailed prairie dog: a case study. The Journal of Environmental Education 39(4) 3-14. https://doi.org/10.3200/JOEE.39.4.3-14

Franck, K. A. \& Stevens, Q. (eds.) (2007) Loose space: possibility and diversity in urban life. Routledge, Abingdon.

Franklin, A. (2006) Animal nation: the true story of animals and Australia. UNSW Press, Kensington.

Gilbert, O.L. (1989) The ecology of urban habitats. Chapman and Hall, New York. https://doi.org/10.1007/978-94-009-0821-5

Griffith, M., Wolch, J. \& Lassiter, U. (2002) Animal practices and the racialization of Filipinas in Los Angeles. Society \& Animals 10(3) 221-248. https://doi.org/10.1163/156853002320770056

Gröning, G. \& Wolschke-Bulmahn, J. (2003) The native plant enthusiasm: ecological panacea or xenophobia? Landscape Research 28(1) 75. https://doi.org/10.1080/01426390306536

Guitart, D. A., Pickering, C. M. \& Byrne, J. A. (2014) Color me healthy: food diversity in school community gardens in two rapidly urbanising Australian cities. Health \& Place 26 110-117. https://doi.org/10.1016/j.healthplace.2013.12.014

Hard, G. (2001) Natur in der Stadt? Berichte zur deutschen Landeskunde 75(2/3) 257-270.

Head, L. \& Atchison, J. (2008) Cultural ecology: emerging human-plant geographies. Progress in Human Geography 33(2) 236-245. https://doi.org/10.1177/0309132508094075

Hillier, J. \& Byrne, J. (2016) Is extermination to be the legacy of Mary Gilberts cat? Organization 23(3) 387-406. https://doi.org/10.1177/1350508416629455

Hinchliffe, S. (2003) Inhabiting-landscapes and natures. In Anderson, K., Domosh, M., Pile, S. \& Thrift, N. (eds.) Handbook of Cultural Geography, 207-225. Sage Publications, London. https://doi.org/10.4135/9781848608252.n14

Hinchliffe, S. \& Whatmore, S. (2006) Living cities: towards a politics of conviviality. Science as Culture 15(2) 123-138. https://doi.org/10.1068/d351t

Hinchliffe, S., Kearnes, M. B., Degen, M. \& Whatmore, S. (2005) Urban wild things: a cosmopolitical experiment. Environment and Planning D: Society and Space 23(5) 643-658. https://doi.org/10.1068/d351t

Hobbs, R. J., Arico, S., Aronson, J., Baron, J., Bridgewater, P., Cramer, V., Epstein, P., Ewel, J., Klink, C., Lugo, A., Norton, D., Ojima, D., Richardson, D., Sanderson, E., Valladares, F., Vila, M., Zamora, R. \& Zobel, M. (2006) Novel ecosystems: theoretical and management aspects of the new ecological world order. Global Ecology and Biogeography 15(1) 1-7. https://doi.org/10.1111/j.1466-822x.2006.00212.x

Honda, T. (2009) Environmental factors affecting the distribution of the wild boar, sika deer, asiatic black bear and Japanese macaque in Central Japan, with implications for human-wildlife conflict. Mammal Study 34(2) 107-116. https://doi.org/10.3106/041.034.0206

Houston, D., Hillier, J., MacCallum, D., Steele, W. \& Byrne, J. (2017) Make kin, not cities! Multispecies entanglements and 'becoming-world' in planning theory. Planning Theory 1-23. https://doi.org/10.1177/1473095216688042

Howell, R. G. (1982) The urban coyote problem in Los Angeles County. In Marsh, R. E. (ed.) Proceedings of the Tenth Vertebrate Pest Conference (1982), Paper 22. University of California, Davis.

Ingold, T. (2008) Bindings against boundaries: entanglements of life in an open world. Environment and Planning A 40(8) 1796-1810. https://doi.org/10.1068/a40156

Instone, L. (2004) Situating nature: on doing cultural geographies of Australian nature. Australian Geographer 35(2) 131-140. https://doi.org/10.1080/0004918042000249430

Instone, L. \& Sweeney, J. (2014) Dog waste, wasted dogs: the contribution of human-dog relations to the political ecology of Australian urban space. Geographical Research 52(4) 355-364.

https://doi.org/10.1080/0004918042000249430

Jerolmack, C. (2008) How pigeons became rats: the cultural-spatial logic of problem animals. Social Problems 55(1) 72-94. https://doi.org/10.1525/sp.2008.55.1.72

Jessup, D. A. (2004) The welfare of feral cats and wildlife. Journal-American Veterinary Medical Association 225 1377-1385. https://doi.org/10.2460/javma.2004.225.1377

Johnston, C. (2008) Beyond the clearing: Towards a dwelt animal geography. Progress in Human Geography 32(5) 633-649. https://doi.org/10.1177/0309132508089825 
Jorgensen, A. \& Keenan, R. (eds.) (2012) Urban wildscapes. Routledge, Abingdon.

Kellert, S. R. (1991) Japanese perceptions of wildlife. Conservation Biology 5(3) 297-308. https://doi.org/10.1111/j.1523-1739.1991.tb00141.x

Kellert, S. R. (1993) Attitudes, knowledge, and behavior toward wildlife among the industrial superpowers: United States, Japan, and Germany. Journal of Social Issues 49(1) 53-69. https://doi.org/10.1111/j.1540-4560.1993.tb00908.x

Kellert, S. R. \& Westervelt, M. O. (1984) Children's attitudes, knowledge and behaviors towards animals. Children's Environments Quarterly 1(3) 8-11.

Keniger, L., Gaston, K., Irvine, K. \& Fuller, R. (2013) What are the benefits of interacting with nature? International Journal of Environmental Research and Public Health 10(3) 913-935. https://doi.org/10.3390/ijerph10030913

Knight, J. (1999) Monkeys on the move: The natural symbolism of people-macaque conflict in Japan. The Journal of Asian Studies 58(03) 622-647. https://doi.org/10.2307/2659114

La Trobe, H. L. \& Acott, T. G. (2000) A modified NEP/DSP environmental attitudes scale. The Journal of Environmental Education 32(1) 12-20. https://doi.org/10.1080/00958960009598667

Lambert, J. E. (2016) Regeneration of human-modified landscapes: the irony of antipathy to resilient animals. EnviroSociety 19.1.2016. <http://www.envirosociety.org/2016/01/regeneration-of-humanmodified-landscapes-and-the-irony-of-antipathy-toward-resilient-animal-species/> 27.10.2017.

Lemelin, R. H. (2013) To bee or not to bee: whether 'tis nobler to revere or to revile those sixlegged creatures during one's leisure. Leisure Studies 32(2) 153-171. https://doi.org/10.1080/02614367.2011.626064

Lorimer, J. (2012) Multinatural geographies for the Anthropocene. Progress in Human Geography 36(5) 593-612. https://doi.org/10.1177/0309132511435352

Lososová, Z., Chytrý, M., Tichý, L., Danihelka, J., Fajmon, K., Hajek, O., Kintrova, K., Lanikova, D., Otypkova, Z. \& Rehorek, V. (2012) Biotic homogenization of Central European urban floras depends on residence time of alien species and habitat types. Biological Conservation 145(1) 179184. https://doi.org/10.1016/j.biocon.2011.11.003

Lyytimäki, J., Petersen, L. K., Normander, B. \& Bezák, P. (2008) Nature as a nuisance? Ecosystem services and disservices to urban lifestyle. Environmental Sciences 5(3) 161-172. https://doi.org/10.1080/15693430802055524

Mace, G.M., Norris, K. \& Fitter, A. H. (2012) Biodiversity and ecosystem services: a multilayered relationship. Trends in Ecology \& Evolution 27(1) 19-26. https://doi.org/10.1016/j.tree.2011.08.006

Matsuoka, R. H. \& Kaplan, R. (2008) People needs in the urban landscape: Analysis of landscape and urban planning contributions. Landscape and Urban Planning 84(1) 7-19. https://doi.org/10.1016/j.landurbplan.2007.09.009

McKiernan, S. \& Instone, L. (2016) From pest to partner: rethinking the Australian White Ibis in the morethan-human city. Cultural Geographies 23(3) 475-494. https://doi.org/10.1177/1474474015609159

McKinney, M. L. (2008) Effects of urbanization on species richness: a review of plants and animals. Urban Ecosystems 11(2) 161-176. https://doi.org/10.1007/s11252-007-0045-4

Metzger, J. (2014) Spatial planning and/as caring for more-than-human place. Environment and Planning A 46(5) 1001-1011. https://doi.org/10.1068/a140086c

Miller, J. R. (2005) Biodiversity conservation and the extinction of experience. Trends in Ecology \& Evolution 20(8) 430-434. https://doi.org/10.1016/j.tree.2005.05.013

Millington, N. (2015) From urban scar to 'park in the sky': terrain vague, urban design, and the remaking of New York City's High Line Park. Environment and Planning A 47(11) 2324-2338. https://doi.org/10.1177/0308518X15599294

Nohl, W. (1990) Gedankenskizze einer Naturästhetik der Stadt. Landschaft und Stadt 22(2) 57-67.

Philo, C. (1995) Animals, geography, and the city: notes on inclusions and exclusions. Environment and Planning D: Society and Space 13 655-681. https://doi.org/10.1068/d130655

Power, E. R. (2005) Human-nature relations in suburban gardens. Australian Geographer 36(1) 39-53. https://doi.org/10.1080/00049180500050847

Power, E. R. (2009) Border-processes and homemaking: encounters with possums in suburban Australian homes. Cultural Geographies 16(1) 29-54. https://doi.org/10.1177/1474474008097979

Qviström, M. (2012) Taming the wild: Gyllin's Garden and the urbanization of a wildscape. In Jorgensen, A. \& Keenan, R. (eds.) Urban wildscapes, 187-200. Routledge, Abingdon.

Rink, D. \& Emmrich, R. (2005) Surrogate nature or wilderness? Social perceptions and notions of nature in an urban context. In Kowarik, I. \& Körner, S. (eds.) Wild urban woodlands, 67-80. Springer, Berlin. https://doi.org/10.1007/3-540-26859-6 4 
Rosenzweig, R. \& Blackmar, E. (1992) The park and the people: a history of Central Park. Cornell University Press, New York.

Rupprecht, C. D. D. (2017) Informal urban green space: residents' perception, use, and management preferences across four major Japanese shrinking cities. Land 6(3) 59. https://doi.org/10.3390/land6030059

Rupprecht, C. D. D. \& Byrne, J. A. (2014a) Informal urban green-space: comparison of quantity and characteristics in Brisbane, Australia and Sapporo, Japan. PLoS ONE 9(6) e99784. https://doi.org/10.1371/journal.pone.0099784

Rupprecht, C. D. D. \& Byrne, J. A. (2014b) Informal urban greenspace: a typology and trilingual systematic review of its role for urban residents and trends in the literature. Urban Forestry \& Urban Greening 13(4) 597-611. https://doi.org/10.1016/j.ufug.2014.09.002

Rupprecht, C. D. D. \& Byrne, J. A. (2016) Informal urban greenspace perception and use: survey instrument. http://doi.org/10.13140/RG.2.1.3830.7448

Rupprecht, C. D. D., Byrne, J. A. \& Lo, A. Y. H. (2016) Memories of vacant lots: how and why residents used informal urban greenspace as children and teenagers in Brisbane, Australia and Sapporo, Japan. Children's Geographies 14(3) 340-355. https://doi.org/10.1080/14733285.2015.1048427

Rupprecht, C. D. D., Byrne, J. A., Garden, J. G. \& Hero, J-M. (2015a) Informal urban green space: a trilingual systematic review of its role for biodiversity and trends in the literature. Urban Forestry \& Urban Greening 14(4) 883-908. https://doi.org/10.1016/j.ufug.2015.08.009

Rupprecht, C. D. D., Byrne, J. A., Ueda, H. \& Lo, A. Y. H. (2015b) 'It's real, not fake like a park': residents' perception and use of informal urban green-space in Brisbane, Australia and Sapporo, Japan. Landscape and Urban Planning 143 205-218. https://doi.org/10.1016/j.landurbplan.2015.07.003

Sapporo Kankyōkyoku Midori No Suishinbu (2013) Bear sighting information. City of Sapporo, Sapporo. <http://www.city.sapporo.jp/kurashi/animal/choju/kuma/syutsubotsu/index.html>. 27.10.2017.

Sapporo Shichō Seisakujitsu Kōhōbu Shimin No Koe O Kiku Ka (2011) Heisei 23nendo dai1kai shimin anke-to chōsa kekka: te-ma4 seibutsu taiyōsei ni tsuite. City of Sapporo, Sapporo. <http://www. city.sapporo.jp/somu/shiminnokoe/sakusei/documents/seibutsutayousei.pdf> 27.10.2017.

Sawaki, M. \& Kamihogi, A. (1995) Study on the residents' taste for coexisting with nature life in the new town. Journal of the Japanese Institute of Landscape Architecture 58(5) 133-136. https://doi.org/10.5632/jila.58.5133

Seymour, M. \& Wolch, J. (2009) Toward zoöpolis? Innovation and contradiction in a conservation community. Journal of Urbanism: International Research on Placemaking and Urban Sustainability 2(3) 215-236. https://doi.org/10.1080/17549170903466020

Soga, M., Yamaura, Y., Aikoh, T., Shoji, Y., Kubo, T. \& Gaston, K. J. (2015) Reducing the extinction of experience: association between urban form and recreational use of public greenspace. Landscape and Urban Planning 143 69-75. https://doi.org/10.1016/j.landurbplan.2015.06.003

Sukopp, H. (2002) On the early history of urban ecology in Europe. Preslia 74 373-393.

Trigger, D. S. \& Head, L. (2010) Restored nature, familiar culture: contesting visions for preferred environments in Australian Cities. Nature and Culture 5(3) 231-250. https://doi.org/10.3167/nc.2010.050302

Trigger, D., Mulcock, J., Gaynor, A. \& Toussaint, Y. (2008) Ecological restoration, cultural preferences and the negotiation of 'nativeness' in Australia. Geoforum 39 1273-1283. https://doi.org/10.1016/j.geoforum.2007.05.010

Ueda, H. \& Rupprecht, C. D. D. (2014) The role of green spaces in the city image of Sapporo. Journal of The Japanese Institute of Landscape Architecture 77(5) 487-490. https://doi.org/ 10.5632/jila.77.487

Urbanik, J. (2012) Placing animals: an introduction to the geography of human-animal relations. Rowman \& Littlefield, Lanham, MD.

Wandersee, J. H. \& Schussler, E. E. (1999) Preventing plant blindness. The American Biology Teacher 61(2) 82-86. https://doi.org/10.2307/4450624

Ward, K. (2010) Towards a relational comparative approach to the study of cities. Progress in Human Geography 34(4) 471-487. https://doi.org/10.1177/0309132509350239

Wittig, R. \& Becker, U. (2010) The spontaneous flora around street trees in cities-a striking example for the worldwide homogenization of the flora of urban habitats. Flora 205(10) 704-709. https://doi.org/10.1016/j.flora.2009.09.001

Wolch, J. (1996) Zoöpolis. Capitalism Nature Socialism 7(2) 21-47. https://doi.org/10.1080/10455759609358677

Wolch, J. (2002) Anima urbis. Progress in Human Geography 26(6) 721-742. https://doi.org/10.1191/0309132502ph400oa 
Wolch, J. R., West, K. \& Gaines, T. E. (1995) Transspecies urban theory. Environment and Planning D: Society and Space 13(6) 735-760. https://doi.org/10.1068/d130735

Yeo, J-H. \& Neo, H. (2010) Monkey business: human-animal conflicts in urban Singapore. Social \& Cultural Geography 11(7) 681-699. https://doi.org/10.1080/14649365.2010.508565 